\title{
GRZEGORZ HOŁUB
}

\section{THE PHILOSOPHER AS THE THERAPIST: A LESSON FROM THE PAST}

\section{INTRODUCTION}

When we take a glance at the contemporary philosophy, we realize relatively easily that this discipline is not a part of therapeutic practices in a strict sense. Neither a medical practice nor a psychological one includes what philosophers have to offer. Sometimes philosophy is used within a socalled ethical counselling (e.g. practiced by bioethical committees) as an introductory part of a proper medical treatment. However, an idea that philosophy by itself brings with it something, which has a therapeutic character is not a part of a mainstream perception of this discipline. Moreover, many contemporary philosophers are unwilling to acknowledge that what they do is a part of therapy. It is a result of a scepticism concerning such categories as the truth or universal goals of human life, etc. In other words, a good number of philosophers have no aspirations to lead people to the discovery of objective truths nor their life goals. Of course, there are notable exceptions like Victor Frankl and his logotherapy, ${ }^{1}$ Abraham Maslow and his humanist psychology ${ }^{2}$ or more contemporary Elliot Cohen and his logic-based therapy. ${ }^{3}$ However, majority of the thinkers would admit that what they do

Ks. dr hab. Grzegorz HoŁub, prof. UPJPII - Papieski Uniwersytet Jana Pawła II w Krakowie, Wydział Filozofii, Katedra Bioetyki; adres do korespondencji: ul. Kanonicza 9, 31-002 Kraków; e-mail: grzegorz.holub@upjp2.edu.pl; ORCID: https://orcid.org/0000-0003-1908-8893.

${ }^{1}$ E.g. Victor FrankL, Man's Search for Meaning. An Introduction to Logotherapy (Boston, MA: Beacon Press, 2006).

${ }^{2}$ E.g. Abraham H. Maslow, Toward a Psychology of Being (Floyd, VA: Sublime Books, 2014).

${ }^{3}$ Elliot D. CoHEN, Theory and Practice of Logic-based Therapy: Integrating Critical Thinking and Philosophy into Psychotherapy (Newcastle upon Tyne: Cambridge Scholars Publishing, 2013). 
could be counted as an indirect therapy by counselling, instructing and inspiring people.

The latter leads us to a preliminary thesis that therapy-oriented activities are indeed present among philosophers. At any rate, many of them treat our present human condition as a subject matter of their philosophizing. Consequently, they want to be teachers of the contemporary man and entertain an ambition to shape culture and ways of developments of the world of today. Particularly, philosophers tend to enlighten us by telling us something more about ourselves and our life projects and strategies; for instance, they attempt to lead us to discover new horizons for our existence and thereby point to whom we could and should become. In this way, they suggest what we are to abandon and from what matters we should liberate ourselves. If we associate our problems and woes with our present life condition, what philosophers do should be indeed considered as a form of therapy.

The topic of the paper suggests a very complex and long-standing tendency in the world of philosophers. Understandably, we cannot delve into a broader set of particular debates. In this article, we are going to concentrate on and analyse only one example of a possible discussion occasioned by an attempt by a group of contemporary philosophers involved in a socalled human enhancement. What is of special interest for us is its 'therapeutic' and enlightening tendency. Once we establish what kind of therapy they propose, we will compare this with selected proposals taken from the Ancient philosophy, when such concepts were very popular and important. ${ }^{4}$ We will try to determine who is to teach whom: are the insights from the past relevant for the present or vice versa? Then, we will be concerned with a question of what, if any, can be taken from the ancients as a lesson.

\footnotetext{
${ }^{4}$ Two remarks should be made here. Firstly, we are not going to make an in-depth study of a particular ancient philosopher as far as a therapeutic-like tendency is concerned. Rather, a general picture of that will be presented by drawing upon the analyses of Julia Annas, who is a great specialist of the Ancient philosophy. Secondly, it is worth pointing out, that those ancient proposals are not a matter of the past. In the contemporary philosophy there are some thinkers who find them still interesting and try to work out creative developments for them (e.g. Martha Nussbaum, Pierre Hadot, and Michel Foucault).
} 


\section{TOWARD RELIVING OF HUMAN CONDITION IN THE CONTEMPORARY TIMES}

Many contemporary philosophers involved in thinking on practical issues ponder how to use the newest scientific and technological innovations in order to relieve hardships and limits of human life. For instance, there is already a huge body of literature concerning a so-called human enhancement. In that we can find very nuanced considerations not only on how to apply the latest discoveries of genetics, genetic engineering and pharmacology into curing various diseases but, more importantly, into making people's lives better. Although the latter is a very spacious concept and thereby quite imprecise, it is usually understood as an indicator of upgraded personal characteristics such as the length of people's lives, a level of intelligence, resistance against illnesses, and even betterment of human's morality. Tendency to move people's lives to a higher qualitative level seem to be - for many thinkers - not only a praiseworthy and desirable enterprise but even obligatory. $^{5}$

What is important to notice at the outset is the hypothetical character of many enterprises those philosophers refer to. For instance, we do not know yet how to make people live radically longer, - say 300 years. We also have quite limited knowledge on how to manipulate on human genetic make-up in order to make individuals considerably more intelligent, smart or morally better. All these achievements are for now in the sphere of theoretical prediction and even speculation. However, genetic knowledge and corresponding practices within genetic engineering go ahead very quickly and some major breakthroughs can be matters of approaching decades. Even now, we have access to some technical interventions that shed some light, at least partially, on future possibilities as to how to modify our human biological structures. ${ }^{6}$ Hence, theoretical attempts to think them over seem to be justified and even needed.

Adherents of human enhancement offer various reasons speaking for the necessity of this tendency. John Harris concentrates on human 'improving' attempts to make the world a better place. He is aware that that "will have to

\footnotetext{
${ }^{5}$ E.g. John Harris, Enhancing Evolution. The Ethical Case for Making Better People (Princeton, London: Princeton University Press, 2007), 37.

${ }^{6}$ For example, Nick Bostrom and Julian Savulescu point to gene therapy on zygotes, gametes, or even on the reproductive systems of adults. Nick Bostrom and Julian SAVULESCU, "Human Enhancement Ethics: The State of the Debate," in Human Enhancement, ed. Julian Savulescu and Nick Bostrom (Oxford: Oxford University Press, 2009), 10.
} 
include not only changes to the world, but also changes to humanity, perhaps with the consequences that we, or our descendants, will cease to be human in the sense in which we now understand that idea". ${ }^{7}$ The philosopher considers the human being as a product of evolutionary processes and that is why, in his opinion, it is high time for us to take control over that slow natural process and replace "natural selection with deliberate selection, Darwinian evolution with "enhancement evolution". ${ }^{8}$ The point Harris wants to convey is that we as natural creatures depend - to a certain degree - on the blind mechanism of nature and it is vital to take control over them and lead our further development according to our knowledge and wisdom. This development concerns all spheres of human life, including our morality. Thus, a first therapeutic counsel consists in the understanding of our basic human condition and then in taking it into our 'intelligent' hands.

What are the goals of our progressive control over our lives? The answer has been already suggested: we are to make ourselves better, meaning by that living longer, being more intelligent, more morally correct. In radical positions represented by transhumanism, for instance by Ray Kurzweil or John Harris, we are to become post-human creatures belonging to a different, radically enhanced species. ${ }^{9}$ Generally, human enhancement is intended as a strategy aimed at helping us to attain a higher level of wellbeing and selffulfilment. ${ }^{10}$ The latter categories are of course quite complex. Savulescu, Sandberg and Kahane consider wellbeing within a welfarist account and point out that various theories can serve as its interpretations, namely hedonistic, desire-fulfilment, and objective list theories. ${ }^{11}$ At any rate, wellbeing is a very important term within a modern utilitarian theory and to a certain degree can be treated as an equivalent of happiness. Thus, we can contend that human enhancement is essentially associated with attaining of happiness in a broad sense.

However, adherents of the human enhancement project consider wellbeing and happiness as states that can be attained by modification of personal

\footnotetext{
${ }^{7}$ HARRIS, Enhancing Evolution. The Ethical Case for Making Better People, 3.

${ }^{8}$ Ibidem, 4.

${ }^{9}$ Ray KurzweIL, The Singularity Is Near: When Humans Transcend Biology (London: Penguin Books, 2006). John Harris, How to Be Good. The Possibility of Moral Enhancement (Oxford: Oxford University Press, 2016), 52.

${ }^{10}$ Erick PARENS, "Toward a More Fruitful Debate about Enhancement," in Human Enhancement, 187.

${ }^{11}$ Julian Savulescu, Anders Sandberg, and Guy Kahane, "Well-Being and Enhancement," in Enhancing Human Capacieties, ed. Julian Savulescu, Ruud ter Meulen, and Guy Kahane (Malden, Oxford: Wiley-Blackwell, 2011), 10.
} 
characteristics. The latter are understood as features coming from psychological sphere and, in the end, from human biology. Thus, for instance, intelligence is basically a matter of our brain, ${ }^{12}$ "altruism and the sense of justice have biological bases" ${ }^{\prime 13}$ as well as all other moral attitudes. Consequently, to gain control over these characteristics we are to employ tools changing our genetic structure or modifying our nerve and brain systems. As a commentator of this position summarizes, "by changing the 'biology' of a person one can influence the way they feel about certain actions and events and, as a consequence, how they behave and how they judge those actions and events morally". ${ }^{14}$ In the long run this model of therapy aims at changing a human nature; as Chantal Delsol puts it, this tends to achieve a kind of renaturalization of the human being by getting rid of pain and death, and thereby eliminating the tragic character of the human condition (conditio humana)..$^{15}$

Who is then a therapist in this position? There is no simple answer to that question. As we could see, the philosophers taking part in the debate aspire to play such roles because they discern a condition of people and can deliver a suitable justification of what to change and why. However, the philosophers have no specialist knowledge as to how to precisely implement desirable changes (although they got acquainted with them). People need here to make recourse to specialists in the field of genetics, genetic engineering, pharmacology, medicine and psychology. Some specialists are to discern empirical conditions and existing possibilities of changing them; others will implement them by modifying for instance, a genetic make-up; yet others will oversee health conditions of an enhanced subject, including possible side-effects (medical doctors); finally, psychologists will be responsible for asserting whether a person undergoing a given procedure has ended up in better condition measured objectively (e.g. by a higher level of intelligence) and subjectively (e.g. by personal satisfaction).

\footnotetext{
${ }^{12}$ Nick Bostrom, Superintelligence. Paths, Dangers, Strategies (Oxford: Oxford University Press, 2014), 43 ff.

13 Igmar Persson and Julian SAVulescu, Unfit for the Future. The Need for Moral Enhancement (Oxford: Oxford University Press, 2012), 109.

${ }^{14}$ Michael Hauskeller, Better Humans? Understanding the Enhancement Project (Durham: Acumen, 2013), 46.

${ }^{15}$ Chantal Delsol, La Haine du Monde. Totalitarismes et postmodernité (Paris: Les Editions du Cerf, 2016), ch. VIII.
} 


\section{RELIEVING THE HUMAN CONDITION IN THE ANCIENT TIMES}

Practice of medicine in the Ancient times was associated with philosophy in many ways. Firstly, many medical doctors were involved actively in philosophy, that is, they practiced medicine and conducted philosophical analyses, like for instance Aristotle. Secondly, there was a widespread conviction that as medicine is a treatment of the body, so philosophy is concerned with a treatment of the human soul. A good example of such a conviction is provided by the Ancient doctor Galen, "It is not true that whereas there is an art, called medicine, concerned with the diseased body, there is no art concerned with the diseased soul, or that the latter (art) should be inferior to the former in the theory and treatment of individual cases." $" 16$ Philosophy should be considered a practical enterprise ${ }^{17}$ and it is equally important as medicine because it is concerned with one of the essential spheres of human life, namely with its spiritual dimension. We will treat this dimension, signified by the soul, as a sui generis reality which is not derived from the body and cannot be reduced to it. ${ }^{18}$

Galen citing Chrysippus (the cofounder of Stoicism) points to an important comparison between a medical doctor and a philosopher, "therefore just as the physician of the body must be "inside", as they say, the affections that befall the body and the proper cure for each, so it is incumbent on the physician of the soul to be "inside" both of these (things) in the best possible way." ${ }^{19}$ This being "inside" stands for an adequate knowledge of the body

${ }^{16}$ GALEN, "The On the Views of Hippocrates and Plato", in Julia E. ANNAS, "Philosophica Therapy, Ancient and Modern," in Bioethics. Ancient Themes in Contemporary Issues, ed. Mark G. Kuczewski and Ronald Polansky (Cambridge, MA, London: A Bradford Book of MIT Press, 2002), 109.

${ }^{17}$ Pierre Hadot, in his famous book, points to the Stoics's understanding of philosophy as a practical exercise. He presents this approach underlining that it "did not consist in teaching an abstract theory - much less in the exegesis of texts - but rather in the art of living." Pierre HADOT, Philosophy as a Way of Life. Spiritual Exercises from Socrates to Foucault, trans. Michael Chase, ed. Arnold I. Davidson (Oxford: Blackwell Publishers Ltd., 1995), 83.

${ }^{18}$ Such a presupposition does not include all understandings of the soul in the Ancient philosophy. For instance, as Martha Nussbaum claims, Epicureans and Stoics were physicalists. Martha Nussbaum, The Therapy of Desire. Theory and Practice in Hellenistic Ethics (Princeton, London: Princeton University Press, 1994), 13. However, in the Platonic and Aristotelian traditions, with all differences dividing these schools, the soul cannot be reduced to the matter. If today we make references to the soul, basically we mean concepts stemming from the latter schools.

${ }^{19}$ Galen, "The On the Views of Hippocrates and Plato," 109. 
and the soul. As Julia Annas puts it, doctor and philosopher "must understand what is troubling the patient, from the patient's point of view, if they are to be able to cure it." ${ }^{20}$ Of course, medical knowledge of the ancients was very poor and, comparing it to what we know today in biomedical sciences, can be even considered as non-knowledge at all. Nevertheless, ancient doctors were, at times, successful in bringing relieve to patients, especially in lighter cases. As to the philosophical knowledge of the "inside", it must be said that "the knowledge of the soul" was steadily progressing especially after Socrates' turn from the interest in the physical nature of the world to the concentration on the human being.

What was typical for the ancient medicine was a holistic approach to treatment. Julia Annas puts it very clearly by saying that "within the ancient model, disease, even if local, already is a loss of overall health." ${ }^{21}$ Consequently to cure one organ a doctor must have paid attention to the whole body. To restore health meant to bring a harmony of the whole organism. Moreover, that wholeness was not understood one-sidedly; in non-monistic philosophies of that time the whole encompassed what is material and immaterial alike, namely the body and the soul. For instance, Plato claims that "just as one shouldn't try to heal the eyes without the head, or the head without the body, so one shouldn't try to heal the body without the soul either; [...] since if the whole is not well, it is impossible for part of it to be so."22

For a philosopher to participate in the treatment of the human being was to turn to ethics. The latter was understood as an activity which takes on a task of investigating human life in its entirety and involves both theoretical and practical questions. ${ }^{23}$ The ancient ethics had a twofold character. On the one hand, it consisted in liberating the soul from what is evil that is, from negative feelings and passions. ${ }^{24}$ On the other, it led to unfolding all potentialities, so to speak, inscribed in the human condition. The latter, of course, was strictly associated with such concepts as virtue and happiness. Giovanni Reale points out that, for the ancient thinkers, the virtue is a necessary tool

${ }^{20}$ AnNAS, "Philosophica Therapy, Ancient and Modern," 109.

${ }^{21}$ Ibidem, 115.

${ }^{22}$ Plato, Charmides, 155 e 1-6.

${ }^{23}$ Susan Sauvé MeYer, Ancient Ethics. A Critical Introduction (London, New York: Routledge, 2008), 1.

${ }^{24}$ Democritus held that "medicine cures the body of diseases, and wisdom clears passions from the soul." Democritus, in The Older Sophists, frag. B 31, in AnNAS, "Philosophical Therapy, Ancient and Modern," 116. Understandably, a philosopher is concerned with wisdom and brings cure by applying it to the human soul. 
enabling to actualize who someone is and what his value is. Thus, a real human good consists in a virtue of the soul that, in the end, leads to happiness. $^{25}$

The philosophical treatment had a specific realization. A given individual person was actively involved in such a treatment in this way that he was expected to reveal his ideas, problems, and personal strategies in dealing with them. A space where it was done was a conversation with a philosopher. And only here where a critical exchange took place - as is paradigmatically shown in Socrates' approach - can a proper cure be looked for and carefully considered. As Julia Annas puts it, "the real spell that cures the whole person is nothing less than philosophical discussion." ${ }^{26}$ Generally speaking, a first step in a philosophical treatment consists in the liberation of the soul from false ideas and assumptions, which come both from domination of passions and instincts, as we mentioned above, and from deficiencies of understanding (e.g. a lack of adequate knowledge concerning real goods, inability to think logically, etc.). Only then, can further steps be undertaken namely embarking on right reasoning and in the end - attaining wisdom of life as a guide. In all this process a philosopher plays a role of a teacher of wisdom.

What is important here to stress is an active involvement of the person seeking out the philosophical treatment. If mature philosophical thinking is to change someone's life, this individual must not only be open, honest and sincere but must also cooperate with his advisor, who gives him some tasks to be performed. At times, they can be hard, very demanding and seemingly impossible to face up to. A high degree of freedom and self-determination is indispensible. Annas underlines a subject's involvement in the following way, "[philosopher] is not a professional fixer who can come along and solve your puzzles for you, or remove from you the burden of thinking about your problems and how to solve them. Nor is he a guru figure who requires complete obedience to his demands. He is someone who can help you but who in the end helps you by enabling you to help yourself. [...] In fact, philosophy requires you to do the hard work for yourself." ${ }^{27}$ Thus, we arrive at a surprising conclusion: in the end a needy person is a therapist for himself.

\footnotetext{
${ }^{25}$ Reale puts it this way: "La virtù dell'uomo in senso greco è, pertanto, il pieno e perfetto esplicarsi di ciò che egli è, e di ciò per cui vale. Il vero bene per l'uomo, in tal senso, non può essere se non la virtù della sua anima, il perfetto attuarsi del suo logos: solo da qui può derivare ogni bene, e, dunque, la felicità." Giovanni REALE, Saggezza antica. Terapia per i mali dell'uomo d'oggi (Milano: Raffaelo Cortina Editore, 1995), 94.

${ }^{26}$ ANNAS, "Philosophical Therapy, Ancient and Modern," 112.

${ }^{27}$ Ibidem, 123.
} 
The philosopher assists him, in a sense, empowers him with his words, ideas and understandings, but to accept, digest and apply these elements is the job of the concerned person.

\section{THE PRESENT TEACHING THE PAST OR VICE VERSA?}

There are many differences between these two ways of philosophizing ${ }^{28}$ and approaches to philosophical therapy and hence it may seem that they are too heteronomous and cannot be compared one to the other. However, an attempt to undertake it can be interesting and fruitful. By doing that, at least to a limited extent, we assume that there is indeed something that can be learnt from the past and that the present can - in a sense - illuminate the past.

Firstly, when we consider Chrisippus postulate that the physician of the soul should be inside the body and the soul, we can point to some interesting observations. Contemporary philosophers have a deeper insight into biological processes taking place in the human body than ancient philosophers due to availability of a much more advanced biomedical knowledge. This knowledge, in its dynamic progress, enables us to know better how to cure our diseases but also it opens up a way for speculations on how to 'improve' and 'upgrade' our existence as such. Do these philosophers have equally better insight into the human soul? It seems that this activity is not a part of their interests. They do not mention directly the soul while talking about human enhancement. ${ }^{29}$ From their analyses we can infer that they do not accept the

\footnotetext{
${ }^{28}$ The way how philosophy is conducted by the adherents of human enhancement show that this is a kind of immanentist philosophy, namely the philosophy concerned wholly with the material (empirical) world (even if there is a strong tendency to enlarge a number of possibilities and powers within). In other words, the human enhancement philosophy is devoid of a transcendent horizon. The ancient philosophy, at least in its main schools, was different. In Platonism and even in the thought of Aristotle there were such transcendent tendencies especially when the topic of soul is undertaken and developed. Thus, we can notice, in a sense, a kind of divinization, as an aim of those philosophies. For example, Aristotle when talking about human reason and a rational part of human soul points out that these are the best parts in a human life. At the same time, he stresses that they have divine origin. The human being should tend to dedicate his life to the life of reason, and "man fully bestowed with reason becomes similar to god." ARISTOTLE, Protrepticus, frag. 28. Thus, the life of reason leads to a kind of divinisation.

${ }^{29}$ Such neglect is a consequence of forgetting about non-material dimension of human life. It is a clear simplification and it may stem from a more general tendency, typical for some modern schools of philosophy, to isolate a subject (and its characteristics) from the phenomenon of life, as Robert Spaemann claims. Robert Spammann, Persons: The Difference between 'Someone' and 'Something', trans. Oliver O'Donovan (Oxford: Oxford University Press, 1996), 4.
} 
existence of the soul as an irreducible part of human life. However, they entertain a considerable interest in improving activities which were traditionally ascribed to the soul, like rational acts, knowledge of the good and so on. Thus, human enhancement philosophers are interested in functions of the soul but not in the soul itself. These functions seem to be understood naturalistically that is, as products of evolution or-in a more sophisticated version of contemporary naturalism - emergents of the cerebral and nervous systems. $^{30}$

Secondly, we can ask whether human enhancement philosophers understand their therapy as a holistic one. According to Plato's opinion-quoted above - such a therapy must deal both with the body and the soul. Apparently, there is no place for the soul (at least for its adequate concept) in the contemporary endeavours. Thus, if any kind of holistic activities come here into play, they are indeed materialistically (physicalistically) underpinned strategies. Roughly speaking, they would consist of making our bodies into better evolutionarily functioning organisms. Is that sort of holism, present in the background, viable at all? In the classical tradition the soul plays a central role in the human life. In a sense, the body is or should be subdued to the soul and enable its expression. For instance, as Aristotle claims, the soul is the form or the first actuality of the body made up of various organs. ${ }^{31}$ Thus, the soul was considered as a main 'organizer' of human existence and an element guaranteeing its coherent complexity. If, however, the independent reality of the soul is denied, what is a basic rule organizing the whole human existence? Naturalistic philosophies offer various strategies here, which can be more or less plausible but adherents of human enhancement hardly mention about them.

Thirdly, both approaches to philosophical therapy show interest in morality and ethics. If the ancient attitude tended to liberate the human being from

${ }^{30}$ Thus we can point generally to two concepts of the soul that are rivals in our discussions: a spiritual soul with its various realizations in the ancient philosophy (e.g. Platonic, Aristotelian and Stoic) and a material semi-soul of human enhancement movement. Of course there is a huge difference between them and in a strict sense only the former can be considered a fully-fledged soul. Generally looking, the ancient concept of the soul has no corresponding notion in contemporary philosophy (I owe this point to an anonymous reviewer).

${ }^{31}$ Aristotle, De Anima, II. 1412 a 19; b 5. Because the human soul possesses vegetative, sensitive and mental characteristics, hence various capacities of human life can be analysed in the light of the structure of the soul. For example, Richard Sorabji considers Aristotelian soul as "a set of capacities". See Richard SorabJI, "Body and Soul in Aristotle," Philosophy 49 (1974), 187: $65 \mathrm{ff}$. 
domination of passions and negative feelings, so the similar interest is entertained by human enhancement philosophers. The latter talk, for instance, of elimination of a gene responsible for aggression as underpinning negative feelings and behaviours. However, there are vital differences in this respect as to a method. The ancients wanted to achieve this result through dialogue and adequate understanding on the part of the subject of therapy. The contemporaries in turn, drawing on a recent genetic knowledge, want to engage medical interventions to reach their goal. Scientifically they are better informed and equipped than the ancients, and that can result in a greater efficacy. Moreover, another divergence seems to appear on the horizon. Human enhancement philosophers propose to diminish a level of passions, e.g. aggression, in a literal way, ${ }^{32}$ whereas the ancients were rather oriented at taking control over passions, assuming that in certain contexts such passions can play positive roles (e.g. reaction at injustice). The latter 'liberation' is not an effacement of passions but the control over them performed by a rational creature.

What about a positive orientation of ethics? For the ancients - as we mentioned already - it consisted in the virtue, self-fulfilment and happiness. For the contemporaries in turn it consists in wellbeing and post-human fulfilment. It is not indeed easy to compare thoroughly these two orientations and there are some difficulties. The virtue was understood by the ancients in relation to goals of human life; self-fulfilment was based on thinking in terms of potentialities of human life; happiness was understood in a strict relation to virtues. Many of these terms do not appear in narratives formulated by human enhancement philosophers and even a good number of contemporary philosophers distance themselves from them. They are not familiar with classically understood virtues and corresponding goals of human life; also the language of potentialities is by them either rejected or understood in the vein of scientism (i.e. naturalistically). Thus, without relation to main goals of human life, wellbeing looks like a poorer and restricted version of the ancient self-fulfilment and happiness; post-human fulfilment in turn is a very imprecise state where we are unable to determine main points of reference. ${ }^{33}$

\footnotetext{
${ }^{32}$ For instance, recombination of a gene responsible for aggression - provided that such a gene exists at all - should lead to a literal change in behaviour.

${ }^{33}$ Nicholas Agar, who is in favour of modest human enhancement, warns us against radical enhancement. He points out that we do not know what a post-human state is about; it can equally lead us to something novel and creative but also to forfeiting of human values and culture. See
} 
Finally, we can ponder on personal engagement of the subject of therapy. In the ancient approach the account is clear: the latter must be fully engaged personally and the therapy itself is about increasing a level of his freedom and participation. In the end, he is left on his own, his problems entirely in his hands. What about human enhancement endeavours? The tendency is to change biological structures and in this way influence a given person's activity be it physiological (e.g. a longer lifespan), cognitive (e.g. a higher intelligence, special artistic abilities) or moral (e.g. a higher level of altruism, lower aggression). The subject's free involvement is here less important and sometimes secondary. The therapist tends to implant some novel personalityrelated tendencies and that can be done with a small cooperation of the subject (e.g. passive consent). In extreme situations changes are introduced at the prenatal stage (by manipulating on embryos or foetuses) when an individual has no conscious and free participation in that at all.

That the freedom of a given individual (a subject of therapy) is not at the centre of attention is revealed in a discussion between adherents of human enhancement and its critics. The latter claim that implanting novel and improved tendencies into a given individual, especially when he was not properly informed (e.g. designer babies), amounts to a violation of freedom. ${ }^{34}$ The former reject this criticism claiming that these elements do not violate human freedom: they only constitute 'potentialities' that can remain latent and passive; they do not compel the individual to act upon them. At any rate, this reply reveals, that human enhancement therapist does not need the free cooperation of the subject in the first place. He is convinced that what he does is right despite the understanding and consent of the subject of therapy. It looks as if the therapist wants to treat someone not because of his urgent and obvious needs but because of some 'worthwhile' and 'noble' and, at the same time, distant ideals.

Nicholas Agar Humanity's End. Why Should We Reject Radical Enhancement, (Cambridge, MA, London: The MIT Press, 2010); Nicholas Agar, Truly Human Enhancement. A Philosophical Defence of Limits (Cambridge, MA, London: The MIT Press, 2014).

${ }^{34}$ Or, at least there are some constraints put on our free will. Allhoff et al. put it this way, "if an enhancement, such as a mood-altering drug or neural implant, interferes with or alters our deliberative process, then it is an open question whether or not we are truly acting freely while under the influence of the enhancement." Fritz Allhoff, Patrick Lin, and Jesse Steinberg, "Ethics of Human Enhancement: An Executive Summary," Science and Engineering Ethics 17 (2011): 206. 


\section{CONCLUSIONS}

There is still a place to use the resources of the Ancient philosophy in contemporary debates. Although we cannot apply directly many philosophical categories of the former to problems we are dealing with today, the achievements of the ancient thought can indeed suggest some new solutions, especially as far as the human being is concerned. Accepting the existence of the soul is, to a considerable degree, a guarantee that we do not fall into an anthropological reductionism. However, the character of what is irreducible in human life should be modified. After such philosophers as Karol Wojtyła and Dietrich von Hildebrand, we should perceive it as something that encompasses not only reason and consciousness but also emotions and 'the heart'. The human enhancement philosophers are mainly concerned with human empirical structures, which we can call 'exteriority', and this approach should be complemented by the philosophy inspired by achievements of the Ancient philosophy (although fully developed in some schools of the modern and contemporary philosophy), which seriously underlines the role of human subjectivity, broadly understood, which we can call 'interiority' (the distinction after Wojtyła).

In our analyses, there are two models of therapy and two various modes of participation in it by the philosopher. The ancient philosopher is involved in such an activity as a sage and a counsellor, whereas the contemporary one takes part in it rather as a semi-scientist and an instructor of the futuristic prognosis. Both are able to get inside of the patient but in differing manners. The ancient therapist manages to reach the human interiority, the sphere of subjectivity, and gives advice aimed at strengthening the subject of therapy starting from his spiritual dimension (his thinking and will). The contemporary therapist in turn possesses a wide access to the human exteriority (he is basically inside of what is external, i.e. bodily constitution) and to manners of changing it; his advice goes in the direction of changing the subject as if from outside. However, the latter is done at the expense of diminishing personal involvement of the subject and - what is more important - at the expense of oblivion of the real human interiority and also the ultimate purpose of human life.

The ancient way of therapy can learn from the contemporary one by accepting what biomedical sciences have to offer, that is, how to penetrate better the human exteriority. Thus, a better knowledge on the human objectivity (materiality) and ability to control it is a precious contribution to the 
therapy as such. At the same time the ancient way, for its part, has to offer many valuable insights. Firstly, that external treatment proposed, to a large extent by human enhancement philosophers, is superficial and cannot live up to what the human being as such stands for. Without a decisive turn to the human interiority, to human subjectivity, we still deal with what is secondary in the human life, even if we are able to introduce within it very attractive changes. Secondly, the human interiority cannot be adequately mapped without such coordinates like goals of human life, its essential goods and values, and the virtue. Todays's currents of philosophy, being further prolongations and implementations of Socrates' approach, complement that list with such categories as self-consciousness, self-experience and emotions ('the heart'). If the philosopher embarks on treatment of people's humanity, he must avoid reductionism-like strategies (monistic, physicalist); because if he does not bring with it the help aimed at rescuing and protecting the whole human being, partial achievements can cause more harm than benefit. Then the therapy can end up in hurting rather than in curing.

\section{BIBLIOGRAPHY}

AgAr, Nicholas. Humanity's End. Why Should We Reject Radical Enhancement. Cambridge, MA, London: The MIT Press, 2010.

Agar, Nicholas. Truly Human Enhancement. A Philosophical Defence of Limits. Cambridge, MA, London: The MIT Press, 2014.

Allhoff, Fritz, Patrick Lin, and Jesse Steinberg. "Ethics of Human Enhancement: An Executive Summary." Science and Engineering Ethics 17 (2011): 201-212.

AnNAS, Julia E. "Philosophical Therapy, Ancient and Modern." In Bioethics. Ancient Themes in Contemporary Issues, edited by Mark G. Kuczewski and Ronald Polansky, 109-127. Cambridge, MA, London: A Bradford Book of MIT Press, 2002.

Aristotle, De Anima. Translated by C.D.C. Reeve. Indianapolis: Hackett Publishing Company, 2017.

Aristotle, Protrepticus, edited by Anton-Hermann Chroust. Notre Dame: University of Notre Dame Press, 1964).

Bostrom, Nick. Savulescu, Julian. "Human Enhancement Ethics: The State of the Debate." In Human Enhancement, edited by Julian Savulescu and Nick Bostrom, 1-22. Oxford: Oxford University Press, 2009.

Bostrom, Nick. Superintelligence. Paths, Dangers, Strategies. Oxford: Oxford University Press, 2014.

CoHen, Elliot D. Theory and Practice of Logic-based Therapy: Integrating Critical Thinking and Philosophy into Psychotherapy, Newcastle upon Tyne: Cambridge Scholars Publishing, 2013.

Delsol, Chantal. La Haine du Monde. Totalitarismes et postmodernité. Paris: Les Editions du Cerf, 2016. 
Democritus. In The Older Sophists. Frag. B 31. In Julia E. AnNAS. "Philosophical Therapy, Ancient and Modern." In Bioethics. Ancient Themes in Contemporary Issues, edited by Mark G. Kuczewski and Ronald Polansky. Cambridge, MA, London: A Bradford Book of MIT Press, 2002.

FrankL, Victor. Man's Search for Meaning. An Introduction to Logotherapy, Boston, MA: Beacon Press, 2006.

Galen. "The On the Views of Hippocrates and Plato." In Julian E. Annas. "Philosophical Therapy, Ancient and Modern." In Bioethics. Ancient Themes in Contemporary Issues, edited by Mark G. Kuczewski and Ronald Polansky. Cambridge, MA, London: A Bradford Book of MIT Press, 2002.

Hadot, Pierre. Philosophy as a Way of Life. Spiritual Exercises from Socrates to Foucault. Translated by Michael Chase, edited by Arnold I. Davidson. Oxford: Blackwell Publishers Ltd, 1995.

HARris, John. Enhancing Evolution. The Ethical Case for Making Better People. Princeton, London: Princeton University Press, 2007.

HARris, John. How to Be Good. The Possibility of Moral Enhancement, Oxford: Oxford University Press, 2016.

HAusKeller, Michael. Better Humans? Understanding the Enhancement Project. Durham: Acumen, 2013.

KurzweIL, Ray. The Singularity Is Near: When Humans Transcend Biology. London: Penguin Books, London, 2006.

Maslow, Abraham H. Toward a Psychology of Being. Floyd, VA: Sublime Books, 2014.

Nussbaum, Martha. The Therapy of Desire. Theory and Practice in Hellenistic Ethics. Princeton, London: Princeton University Press, 1994.

PARENS, Erick. "Toward a More Fruitful Debate about Enhancement." In Human Enhancement, edited by Julian Savulescu and Nick Bostrom, 181-197. Oxford: Oxford University Press, 2009.

Persson, Igmar, and Julian SAvulescu. Unfit for the Future. The Need for Moral Enhancement, Oxford: Oxford University Press, 2012.

Plato, Charmides. Translated by Thomas G. West and Grace Starry West. Indianapolis: Hackett Publishing Company, 1986.

Reale, Giovanni. Saggezza antica. Terapia per i mali dell'uomo d'oggi. Milano: Raffaelo Cortina Editore, 1995.

SAuvé Meyer, Susan. Ancient Ethics. A Critical Introduction. London. New York: Routledge, 2008.

Savulescu, Julian, Anders SAndberg, and Guy Kahane. "Well-Being and Enhancement." In Enhancing Human Capacieties, edited by Julian Savulescu, Ruud ter Meulen, and Guy Kahane, 3-18. Malden, Oxford: Wiley-Blackwell, 2011.

SORABJI, Richard. "Body and Soul in Aristotle." Philosophy 49 (1974), 187: 63-89.

Spaemann, Robert. Persons. The Difference between 'Someone' and 'Something.' Translated by Oliver O’Donovan. Oxford: Oxford University Press, 1996. 


\section{THE PHILOSOPHER AS THE THERAPIST: A LESSON FROM THE PAST}

\section{S u m m a ry}

This article is about the philosopher as a potential therapist. It starts from tendencies exhibited by a group of contemporary philosophers involved in a so-called human enhancement. Drawing on the newest discoveries of genetics, genetic engineering and pharmacology, they offer a set of therapies aimed at the extensive 'improvement' of the human condition. In the second part of the paper, selected ideas concerning philosophical therapy by the Ancient philosophers are presented. They basically employed personal contact, conversation, and wise counselling. Then these two approaches to this kind of therapy are compared and contrasted. The contemporary approaches offer novel, technical ways of intervention but are blind as far as far-reaching goals and the essential goods of human life are concerned. Despite serious cultural differences, the contemporary therapy can learn a lot from the ancients. If the human being is to be treated by philosophers, an integral picture of who the former is must be taken into account. This means that both his interiority and exteriority should be subjects to the therapy.

\section{FILOZOF JAKO TERAPEUTA - LEKCJA Z PRZESZŁOŚCI}

Streszczenie

Artykuł dotyczy filozofa, który może pełnić funkcję terapeuty. W pierwszej części ukazane są tendencje do postaw terapeutycznych dostrzegane w środowisku filozofów współczesnych zaangażowanych w tzw. ulepszanie człowieka. Wykorzystując najnowsze osiągnięcia genetyki, inżynierii genetycznej i farmakologii, filozofowie ci oferują terapie ukierunkowane na „ulepszenie" ludzkiej kondycji. W drugiej części artykułu ukazane są wybrane idee dotyczące terapii filozoficznej w postaci, jaką praktykowali niektórzy filozofowie starożytni. Ich propozycje opierały się zasadniczo na kontakcie osobowym, rozmowie i radach o charakterze mądrościowym. W kolejnej części artykułu te dwa podejścia są skontrastowane i porównane. Stanowiska współczesne podkreślają wagę nowych, technicznych metod ingerencji w życie człowieka, ale są ślepe, jeśli chodzi o ujęcie istotnych celów i dóbr ludzkich. Pomimo wielu poważnych różnic kulturowych współczesna terapia może się wiele nauczyć od tej rozwijanej w starożytności. Jeśli istota ludzka ma być poddana terapii praktykowanej przez filozofa, konieczne jest wzięcie pod uwagę jej integralnego obrazu. Oznacza to, że tak jej wnętrze, również jej zewnętrzność powinny stać się przedmiotem ewentualnego oddziaływania terapeutycznego.

Słowa kluczowe: ulepszanie człowieka; filozof współczesny; filozof starożytny; terapia; wnętrze osoby; ludzkie wartości.

Key words: human enhancement; contemporary philosopher; ancient philosopher; therapy; person's interiority; human values.

Information about Author: Rev. Dr. hab. GRZEGORZ HoŁuB - associate professor of philosophy at the Pontifical University of John Paul II in Krakow, Faculty of Philosophy, Department of Bioethics; address for correspondence: ul. Kanonicza 9, 31-002 Kraków, Poland; e-mail: grzegorz.holub@upjp2.edu.pl; ORCID: https://orcid.org/0000-0003-1908-8893. 